\section{PP-321，ビデオ膀胱スコープ(電子䏽胱鏡)の使用 経験一耪胱腔内からの膀睄䅡部観察一}

\begin{abstract}
多根総合病院 泌尿器科"
奈良県立医科大学 泌尿器科

近藤 秀明", 池田 朋博", 堀川 直樹", 林 美樹"

藤本 清秀"', 平尾 佳彦 ${ }^{2}$

(緒言) 1985 年頃より軟性膀胱鏡は硬性鏡と比較し疼痛が軽隇され 有用性が報告されてきたが、画像力が少り普及には至らなかった。(目 的) 2001 年 5 月より、ビデオ膀胱スコープ(ペンタックスECY-1530)を 用いて、尿道および膀胱内の観察を行ってきた。本機種は CCD チップ がファイバー先端に内㬝され硬性鏡に近い画像が得られ、さらに軟性 鏡の利点であるファイバーの先端を 180 度回転(Turn over)させるこ とにより、従来の硬性鏡では充分に膀胱䅡部を観察できなかったが、膀 胱腔内から順行性に観察可能となった。今回、若干の知見が得られた ので報告する。(方法)被験者は仰卧位とし、男性には 4\%Xylocaine の尿道内注入による局所麻酔、女性には無麻酔で観察を行った。男性 では尿道内の観察を行いながら、スコープを膀胱内に挿入した。次に 膀胱内の観察を従来の硬性鏡と同様に行った後に、Turn overにより 膀胱澒部を観察した。(結果)前立腺肥大症の中葉肥大、著明な前立 腺肥大症での尿管口の確認、TUR-P 後の残存腺腫の有無および前 立腺癌に対する前立腺摘除術後の膀胱尿道吻合部などが観察可能 であった。(結語) 疼痛が軽減され、画像も鲜明になったことより、今後は 一般外来での検査だけではなく、Turn overにより膀胱䅡部に对する 内視鏡的手術操作にも応用可能であると考えられた。
\end{abstract}

電子膀胱鏡 軟性鏡

\section{PP-322 マウス皮下腫暍モデルに対する Photody- namic Therapy:連続波照射とナノ秒パル ス波照射による深部治療効果の違いにつ いて}

\section{自衙隊横須賀病院”都立清瀬小坚病院"2) 慶應義塾大学 理工学部物理情報工学科 ${ }^{3)}$ 防衛医科大学校医用電子工 学( 防衛医科大学校 ${ }^{5)}$}

瀬口 健至", 浅沼 宏" ${ }^{21}$, 佐藤 裕之 ${ }^{21}$, 荒井 恒憲 ${ }^{31}$ 川内 聡子“), 菊地 眞 ${ }^{4}$, 浅野 友彦 ${ }^{51}$, 早川 正道 ${ }^{51}$

[目的]光化学㙩法(Photodynamic Therapy. PDT)を悪性腫場に对寸る治療 として用いる際に、光照射方法の工夫により治療效果を高めるととを目的とし i vivo 実駼を行った。(方法)第 2 世代 PhotosensitizerのPAD-S31 使用した。 照射光源しして、連続波半導体レーザー、対ジウム・ヤグレーザー励起光共振発 振器によるナノ秒パルス波(YAG-OPO)を使用し、連続波とナノ秒パルス波照射 の治療效果の違いについて検討した。Renca 細胞をBalb/c マウスの皮下に接 種し、腫韵径 $1 \mathrm{~cm}$ でPDTを施行したPDT 施行 72 時間後に腫場部を切除

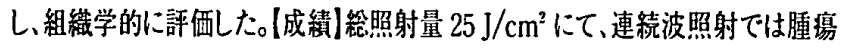
塄死深度は $3 \mathrm{~mm}$ であった。照射強度 $25,50,100 \mathrm{~mW} / \mathrm{cm}^{2}$ の 3 强度間で PDT の効果に差を認めなかった。YAG-OPOでは、腫場壊死染度は $5 \mathrm{~mm}$ にお よび、連较波群と比較しより深部までPDTの効果を諗めたが、25 400 $\mathrm{mW} /$ $\mathrm{cm}^{2}$ の間で照射強度による壊死深度の差は認めなかった。連続波照射では浅部

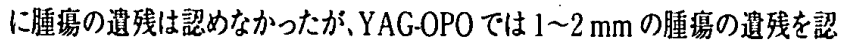

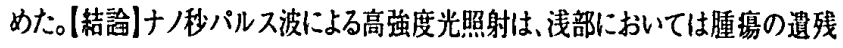

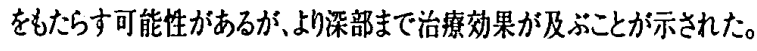
Photodynamic Therapy(PDT) YAG-OPO ナノ秒パルス波

\section{PP-323}

ENDOLUMINAL ULTRASONOGRAPHYによる尿路上皮腫瘍の深達度診断

\section{日本医科大学 泌尿器科}

堀内 和孝, 清水 宏之, 松沢一郎, 佐藤 三洋, 近藤 幸尋 木村 剛, 坪井 成美, 吉田 和弘, 西村 泰司

【目的】尿路上皮腫瘍の深達度診断における high-frequency (20 $\mathrm{MHz}$ ) endoluminal ultrasonography (ELUS)の有用性について検 討した. [方法]腎盂腫瘍 10 例, 尿管腫瘍 10 例, 膀腅腫場 78 例に 対して, high-frequency (20 MHz) ELUS で術前深達度診断を行な い,病理学的深達度と比較した. [成績]筋層浸润に対するELUSの

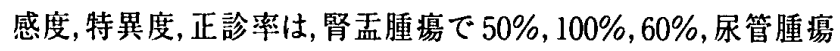
で 100\%,100\%, 100\%,膀胱腫瘍で 80\%, 90\%,88\%であった膀 胼腫瘍の場合, 有茎性腫瑒の正診率は $100 \%$ で, 腫瘍の大きさにか かわらず, 棇ての症例で表在性腫瘍と浸潤性腫瘍の鑑別が可能で あった.しかし, 無茎性腫場では $2 \mathrm{~cm}$ 以下の腫場の感度,特異度, 正 診率は, $67 \%, 83 \%, 77 \%$ で, 浸潤性腫瘍を understaging する傾向 があったが, $2 \mathrm{~cm}$ 以上の腫瘍の感度,特異度, 正診率は, $88 \%, 29 \%$, 60\%で, 表在性腫瘍を overstaging する傾向があった.また，表在性 膀胱腫㿟での粘膜固有層浸润に対する感度, 特異度は, $55 \%, 89 \%$ で, T1 腫瘍を understaging する傾向を認めたが, $79 \%$ の症例で Ta 腫瘍と T1 腫場の鑑別が可能であった. [結論】High-frequency ELUSによる尿路上皮腫瘍の深達度診断は, 腎孟腫瘍, $2 \mathrm{~cm}$ 以上の

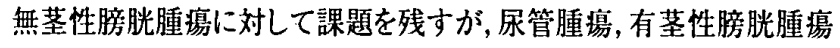
では表在性腫瘍と浸洞性腫場の鑑別に有用であった。

尿路上皮腫場 超音波 深達度診断

\section{PP-324 上部尿路出血に対する尿管鏡下止血術の 検討}

\section{東京女子医科大学}

小林 千佳, 八木沢 隆, 橋本 恭伸, 石田 英樹, 前田 佳子 龍治 修, 中澤 速和, 東間 紘

【目的】画像診断で明らかな病変を診断できない上部尿路出 血に対する尿管鏡、及びレーザー止血術の有用性を検討す る。【対象と方法】対象は、膀胱鏡で上部尿路からの出血が確 認され、画像診断でで明らかな病変がなく、尿細胞診陰性の 7 例である。内訳は男性 3 例/女性 4 例、平均年齢 47 葴、右 㑡 2 例/左㑡 5 例。全身瘚酔下に硬性尿管鏡 (Wolf; $8 \mathrm{Fr}$ ) で尿管を観察、ついで軟性尿管鏡(オリンパス;URF-P3)で腎 内を観察した。出血部位が同定された場合は Holmium レー ザーで止血をした。結果】出血部位の同定が可能で止血術 を行った症例は 4 例で、うち 3 例は術後 1 ケ月で顕微鏡的に も血尿はみとめられない。出血部位の同定ができなかった 3 例のうち 2 例では腎杯内に小結石をみとめ、1 例は腎盕まで の観察不能であったが、 3 例とも術後血尿は消失している。合 併症としては術後腎歪腎炎が1例にみられた。結論】原因 不明の上部尿路出血に対する尿管鏡下止血術は有用であ り、皘極的に試みてよい手技と考えられた。出血病変の同定、 確定診断はときに難しく、さらに症例をかさね検討する必要が ある。

上部尿路出血 (病变) 尿管鏡 レーザー 